\title{
The HSR competition in Italy: how are the regulatory design and practices concerned?
}

\author{
Christian Desmaris ${ }^{\mathrm{a},},{ }^{,}$, Fabio Croccolo ${ }^{\mathrm{b}}$ \\ a. University of Lyon. Transport Urban Planning Economics Laboratory (LAET). ISH. 14 Avenue Berthelot. 69365 Lyon. Cedex 07. France. \\ b. Ministry of Infrastructures and Transport. General Direction for Rail and Marine Investigations. Viale dell'Arte 16, 00144 Roma. Italy. \\ * Corresponding author. Tel.: +33 (0) 472.726.441; fax: +33 (0) 437.283.801. \\ E-mail address: christian.desmaris@sciencespo-lyon.fr
}

\begin{abstract}
Italy is nowadays the only European country to have organized a head-on competition on its whole high speed railway (HSR) network. This paper discusses the issues of this new market structure for the Italian Rail Regulator, both in terms of regulatory design and economic regulation practices. Such HSR competition and regulation took place in a very specific and ambivalent context (including declining Italian railway demand, negative European macroeconomic environment), together with a new ambitious and innovating private competitor (NTV) and strong reactions from the incumbent (Trenitalia). The Italian Rail Regulator's interventions look like more or less a set of everyday life decisions and empirical trade-off than a duly achieved economic doctrine and policy. The level of access charges seems to be a strategic variable to enlarge the scope for profitable entry in Italy. However, this new context still does not answer the question whether HSR operators reach their economic equilibrium in open access competition.
\end{abstract}

Keywords: Rail market; Regulation; High-speed; Open access; Competition; Italy

JEL: R48, L92, L51, L13, L43, R38

VERSION: 13 May 2018 


\section{Introduction}

The European Commission argues that rail renewal contributes to achieving the objective of a sustainable transport system (European Commission, 1996, 2001, 2011; Ponti and al., 2013). Competition is supposed to be the best way to reverse declining competitiveness and attractiveness of rail transport. For long-distance passenger services, European law advocates in favour of 'open access' competition. But, in practice, very few European countries allow on track competition and very few newcomers have decided to enter those markets. New entrants have been deterred by a lack of profitability and by advantages possessed by the largest network operator, the state-owned incumbent. This has limited open access operations to selected niche markets (Nash, 2008; Preston, 2012).

Italy is currently the only European country to have organized an 'open access' competition between the incumbent rail operator and a new company in the high-speed segment (SánchezBorrás, 2015; Pérennes, 2017). In Sweden, Germany or Great Britain, in selected HSR corridors and in smalls periods, on-track competition in passenger services has been opened, whereas in recent years, on a larger scale, Austria and the Czech Republic did (Casullo, 2016; Tomes and alii., 2016), but for those latter countries, it's not on all the network and it doesn't mean a head-on competition.

This intra-modal competition started in April 2012, with the entry of NTV ('Nuovo Trasporto Viaggiatori') on the Italian HSR market yet fully dominated by the state-owned incumbent, Trenitalia. This new market structure interrogates the Italian rail regulator, both in terms of regulatory design than in practice. This paper debates the economic regulation of this new competition on the high-speed market, from a historical, theoretical and practical point of view (Finger and Messulam, 2015; OECD, 2008; OECD, 2013; OECD, 2014). What is the institutional framework of rail regulation in Italy? What economic doctrine does the regulator follow? What kinds of choices is the Italian transport regulator dealing with? Does it promote rail competition or does it protect the incumbent? What measures or tools has it formely used (level of tolls, path allocation, arbitration arrangements and mediation...)? Overall, we will try to draw some lessons from this particular case study for other countries and for the writing of European legislation.

The limited opportunity to step back makes the academic literature still fragmentary. Until now, it was mainly focused on the consequences of competition for travellers and all rail industry actors (Bergantino et al., 2015; Bergantino, 2015; Beria et al., 2016; Beria and Grimaldi, 2016; Cascetta and Coppola, 2013; Mancuso, 2014; Patuelli, 2015), and very rarely on the role and the interventions of the rail regulator, ART (Cambini and Perrotti, 2013; Croccolo and Violi, 2013; Sen and Cini, 2011; Stanta, 2013).

Our methodology will aim at gathering scattered information from diverse sources such as ART Annual Report to Parliament and decisions, articles from professional railway journals and communications presented in non-strictly academic seminars (Transforum, Florence School of Regulation), Italian newspapers and blogs. Data were retrieved from official websites of the Italian Rail Regulator, the Italian Ministry of Transport, Italian railway companies, as well as national and European railway statistics. Moreover, we interviewed major Italian rail actors ${ }^{1}$.

\footnotetext{
${ }^{1}$ Many information or, for the least, confirmation have been collected from meetings with representatives of railway companies or from regulators at seminars organized by The Florence School of Regulation or at "Transforum" conferences. Alberto Mazzola, in charge of the international affairs of Trenitalia in
} 
This paper is structured as follows. (1) What is the context in which the new Italian rail regulation operates? (2) What is the Italian rail economic regulation, both "in the book" ("in law") and "in practice"? (3) What are the main Italian rail regulation outcomes? (4) What are the meaningful results and what lessons can be drawn for policy makers?

\section{The new Italian rail regulation context: the emerging and growing on the track competition in the Italian HSR}

On-track HSR competition in Italy took place in a very specific context: a long term declining Italian railway demand coupled with a negative European macroeconomic environment and physical positive factors. Facing these challenges, the NTV new operator's shareholders opted for an ambitious strategy of costly investments and an innovative rail business model.

\subsection{A long term declining Italian railway trend demand and a detrimental impact of the negative European macroeconomic environment}

Of all the major European countries, the Italian rail passenger transport market belongs to the least dynamic ones. Whereas supply and passenger traffic are increasing in all European countries, sometimes significantly (UK, Switzerland, Spain), since the 1990s this is not the case at all in Italy. The incumbent's railway service offer and demand have both been generally sluggish, expressed both in train supply kilometres or passenger-kilometres

(Table 1).

Table 1. European Railway companies performance

\begin{tabular}{ccccc}
\hline & $\begin{array}{c}\text { Supply 2015 in Train- } \\
\text { kilometres (Million) } \\
\text { (a) }\end{array}$ & $\begin{array}{c}\text { Change since } \\
1995\end{array}$ & $\begin{array}{c}\text { Traffic 2015 in } \\
\text { Passenger- kilometres } \\
\text { (Billion) (b) }\end{array}$ & $\begin{array}{c}\text { Change since } \\
1995\end{array}$ \\
\hline SNCF (France) & 442620 & $43,8 \%$ & 83425 & $50,8 \%$ \\
DB (Germany) & 787556 & $23,0 \%$ & 79655 & $31,6 \%$ \\
FS (Italy) & 284483 & $11,1 \%$ & 39290 & $-10,4 \%$ \\
ATOC (UK) (c) & 528580 & $42,0 \%$ & 62296 & $107,7 \%$ \\
RENFE (Spain) & 170579 & $40,8 \%$ & 24825 & $62,1 \%$ \\
SBB (Switzerland) & 145400 & $60,9 \%$ & 18560 & $58,5 \%$ \\
\hline
\end{tabular}

Source: Our calculations, from UIC. (a) Passenger trains; Table 41. (b) Domestic and international traffic; Table 51. (c) 2014.

The low growth of passenger rail services in Italy is due to two main domestic factors. Firstly, regional authorities did not increase traffic on their territories (Stanta, 2013). Secondly, the Government reduced long distance supply, in part because bus market liberalization has increased competition for long distance travel. As for operators, the low level of subsidization of regional traffic (one of the lowest in Europe - see Cesarini, 2013) leaves little room to invest in the renewal or extension of capacity of the rolling stock.

Besides, part of this sluggish railway demand is also due to the harmful impact of the crisis on the Italian economy (FSI, 2015), compared to other European economies. Based on OECD data (OECD, 2015), 2015 Italian real GDP was $8.5 \%$ less than in 2007, compared with $+3.4 \%$ in France, $+6.4 \%$ in UK and $+6.6 \%$ in Germany. This recession has resulted in a significant and negative impact on transport demand for all modes in Italy (ART, 2015), in particular, in rail traffic: total passenger-kilometres fell from 50.2 billion in 2006 to 44.6 billion in 2012 (an

Brussels, has been interviewed about Trenitalia strategy. Fabio Croccolo, as former General Director of the URSF, the first Italian rail Regulator, has been associated with the writing of this article. 
$11.1 \%$ reduction). By comparison, in France the decrease was only $-0.8 \%$, in Spain $-2.8 \%$ and in Greece $-54.1 \%$, the most crisis-affected European country.

However, the economic crisis is not the only reason for such a weak railway demand. The number of passenger-kilometres in Italy had slightly increased during the 1990s and was stable from 1999 to 2006, about 49 billion per year (UIC, 2013). Historically, the attractiveness of rail in Italy is comparatively rather low. The modal share of rail passenger transport is at the lower rate of the European Union, with $6.1 \%$ of passenger-kilometres in 2012 (EC, 2015), against $7.7 \%$ on average in the EU15 (9.3\% in France, $8.4 \%$ in Germany and $8.0 \%$ in the UK).

It is in this unfavourable rail context that NTV has decided to compete, in particular, in the high speed rail market in Italy. The following part of the paper will try to enlighten and understand such a decision.

\subsection{An ambitious and very innovating Italian entrepreneurship}

NTV was established in December 2006, by several Italian private entrepreneurs, Luca Montezemolo, Diego Della Valle, Gianni Punzo and Giuseppe Sciarrone. Later, the French national railway incumbent (SNCF) entered NTV's shares as "technical partner", without any involvement in the management. Since then, SNCF has sold its shares in 2017. NTV launched its first trains in April 2012 (Baron and Ciry, 2012). NTV's initial objectives were to acquire a 20-25\% market share by 2014-2015, allowing NTV to reach its breakeven from 2014, and to open in a second stage, new destinations - Bologna, Padova, Venice and Turino (Sia Conseil, 2012).

NTV's strategy is based on several principles: a massive investment able to bring a supply shock in the Italian railway market; a modern offer based on differentiated services, on comfort, a modern image, and a unique rail business model in Italy.

NTV displayed an ambitious and long-term choice by immediately opting for a massive investment in rolling stock. To this end, NTV invested over one billion Euros, including €628 million in the purchase of 25 modern AGV trains and $€ 90$ million in the maintenance site in Nola, near Naples (Sciarrone, 2014; Stanta, 2013). For its start-up, NTV has also created approximately one thousand direct jobs and almost the same amount of indirect jobs (Santa, 2013).

Italo (NTV's service brand name) offers different travel environments or classes, as in airplanes: "Smart" (economic), "Comfort" (Smart XL), "Prima" (Business) and "Club Executive" (First Class). Comfort provides a mix between the affordability of Smart and the comfort of Prima. Club is equipped with individual video screens to watch live TV and meeting rooms. Italo also offers free Wi-Fi access in all travel classes, food vending machine (or cold meal service in Prima and Club), displays in each car to preserve the peacefulness of travelers, and a video surveillance security system to secure luggage spaces.

The fundamental innovation provided by NTV on the Italian railway market lies in its business model (Sia Conseil, 2012). The NTV's cost structure is inspired by the 'low cost' airline. Fixed costs are minimized, with overwhelmingly digital distribution. Customers can still buy tickets directly on trains or terminals in main train stations but not in every network station. The innovative pricing system is based on yield management as in France (the expertise of its partner, SNCF). Many tasks are outsourced: maintaining costs of rolling stocks, catering, security and the call center. The objective is to cut the costs in order to lower the profitability point. Furthermore, NTV staff management introduced a new incentive-based remuneration model. The share of individual and collective incentives is high. The fixed salary increases by 
$25 \%$ thanks to a system of individual and collective premiums. There is also a profit sharing arrangement based on firm results. Thus, it seems that NTV's strategy is aimed at enhancing services quality while increasing productivity.

\subsection{Some physical positive factors}

The launch of the high-speed rail NTV's offer could be analyzed as an opportunist decision to take advantage of several favorable objective factors.

First, geographic and demographic characteristics offer strong opportunities to the Italian HSR network. Most economic activities in Italy are concentrated in the north. In this area, most cities are separated by distances of $150-250 \mathrm{~km}$, which makes HSR competitive against air and car traffic due to big traffic congestion on approach into cities (Cascetta and Coppola, 2013). This is consistent with Vickerman (1997) who shows, that for distances between 200 and 600 kilometres, HSR has a clear advantage on air travel. The Milan-Rome corridor has these features (two of Italy's most populous cities), which are separated by just over $500 \mathrm{~km}$. Nash (2015) points out that serving a large population, by example in a string of large cities, is crucial for HSR success.

Secondly, successive Italian governments have generously invested in the national HSR network - spending around $€ 50$ billion until now, which was the largest public investment in Italy for decades (Beria and Ponti, 2008). Building and opening up this network has made competition possible. In all network industries, quality and open access of the infrastructure are among the main conditions to ensure profitable competition (Finger and Künneke, 2011; Knieps, 2015). The Italian high-speed railway network was substantially completed over the 2006-2009 period. The first link, the "Direttissima", was partially opened in 1977, connecting Rome and Città Della Pieve (central Italy), while the whole route between Rome and Florence (257 km) was completed in 1992. In the late 2000s, several new lines were successively put into operation: Roma-Napoli and Turin-Novara (2006), Milan-Bologna (2008) and in 2009, Novara-Milan, Florence-Bologna and Naples-Salerno (UIC, 2014). Other line extensions are already planned, including Milan-Venice $(245 \mathrm{~km})$, which will open approximately in 2020 . The heart of the HSR (or TAV "Treno Alta Velocità") network will form a "T", extending from north to south of the peninsula, connecting Turin to Salerno-Venice with the axis Milan-Rome as main corridor. Most of the Italian HSR network can now sustain a maximum speed of $300 \mathrm{~km} / \mathrm{h}$, but it will probably be improved up to $350 \mathrm{~km} / \mathrm{h}$.

Upon its entry on the market, NTV had benefited from a quasi-completed high-speed network of 923 kilometres. The all rail network served by HS trains is even more important because High-speed trains can also run on the conventional rail network, at lower speeds, to maximize the network effects.

Thirdly, at the end of the 2000s, the incumbent Trenitalia HSR offer was still somewhat limited. In 2011, the share of HSR in the total of rail transport, expressed in passenger-kilometres, was $26.2 \%$ in Italy, which is relatively undeveloped compared to peers in the EU: $27.4 \%$ in Germany, 49.3\% in Spain and even 58.5\% in France (EC, 2015).

Up to this point we have focused on the on-track Italian HSR competition context. In the following part we will highlight the issues, initiatives and decisions which the new Italian transport regulator had to face in order to regulate the HSR open access competition. 


\section{The rail regulator matters: in the law and in practice}

Economic regulation is a crucial question for all liberalized network markets (Baldwin et al., 2012). In the railway sector, the most recently liberalized one in Europe (Finger and Messulam, 2015), this subject is rather new, especially in Italy where open access competition has just started.

In order to identify how the Italian Regulator was concerned by HSR competition, we will first present the regulation 'in the book' (or "in law") and then 'in practice'.

\subsection{The rail regulation of open access competition in Italy: 'in the law'}

To understand the possibilities and the targets of the new Italian railway regulator, ART, we will underline the main liberalization steps of the railway markets in Italy.

\subsubsection{An institutional framework precociously opened to the changing European doctrines in favour of rail competition, at least in the law}

Railway reforms began early in Italy. At the end of the 1980s, the Government started restructuring Italian railways to increase their efficiency and effectiveness. It carried out a successful program, also following the European railway reform. Ferrovie dello Stato (FS) today renamed Ferrovie dello Stato Italiane (FSI) - was established in 1985 as an autonomous undertaking, ceasing to be a department of the Ministry of Transportation. In 1992 it became a wholly-state-owned, joint-stock company (Senn and Cini, 2011). Such changes were also part of a wider privatization program which had its peak in the 1990s (Anselmi, 2014). The company was then pressed to reach an economic and financial equilibrium. This target has been accomplished mainly by strong controlling costs and by raising passenger tariffs. The workforce has been subsequently reduced by more than $65 \%$, from over 220,000 in 1980 to about 72,000 in 2012, as a part of a major restructuring. In Italy, the staff downsizing has been more drastic and tougher than in most of others European countries (from UIC data). A new divisional organization was also implemented in Trenitalia more focused on markets and on customers.

Complying with the European railway legislation, in 1997-1999, the Italian government (Decree of the President $277 / 1998$ ) decided to separate the previous vertically integrated competences of FSI: passenger service management was assigned to Trenitalia, while the management of railway lines was assigned to the new infrastructure manager, i.e. Rete Ferroviaria Italiana (RFI). RFI is now responsible for the maintenance of infrastructure, the traffic management, the allocation of rail capacity (in terms of train paths or time slot) and the control activities rail services companies, with regard to circulation safety. Both Trenitalia and RFI are $100 \%$ owned by FSI (Cascetta and Coppola, 2013).

Before many other Western European countries, the Italian railway regulation has responded to the changing European reforms in favor of rail competition (IRG-Rail, 2017). As for freight, for long-distance trains (HST on dedicated infrastructures; very fast trains on conventional infrastructures, including tilting, most of the InterCity service), competition among the railway undertakings is the rule and public subsidies are admitted only for specific and limited obligations. Open access has been in force over the rail network for these services since 2001, well before it should have become compulsory for the whole EU. Nevertheless, in practice, before delivering an internal license, Italian regulation (Law 388/2000) asks for the same rights in the foreign country where the railway undertaking $(R U)$ to be licensed is based, according to the reciprocity principle (Stanta, 2013). Likewise, Trenitalia, as the railway operator lost its monopoly and became a licensed RU just like its competitors (Senn and Cini, 2011). The 
liberalization of freight market has produced much more competitive results (ART, 2015; Stanta, 2013): the market share of the newcomers reaches about $30 \%$ and more on some international corridors (40\% in Brennero route) (Cesarini, 2013).

For the subsidized markets, including the whole regional traffic and some InterCity, there is another kind of competition ('for the market'). Each group of routes is run by one railway undertaking and each railway undertaking has to sign a public service contract (PSC) with the Regional Government which is responsible for the area. Italian Regions, since 1999, have been allowed to choose how to allocate their PSCs, with or without competitive tendering, but in practice most of them preferred to award without competitive tendering. Only 4 Regions have called for tenders lots for their entire service in the years 2003-2007, and they often incurred difficulties and unsatisfactory results (Cesarini, 2013; Stanta, 2013).

Globally, theoretically and well ahead of the deadlines set by the European Union, the Italian railway sector is an open market just like Germany, Great-Britain and Sweden². However, in practice, there are still obstacles and the share of new competitors in passenger traffic remained very low before the arrival of NTV (Senn and Cini, 2011).

\subsubsection{The Italian Transport Regulation Authority (ART): A learning process for a very new one among big European countries}

Although railway liberalization process in Italy was one of the earliest in Europe, paradoxically regulations have stayed for a long time under the prerogatives of the Government (Senn and Cini, 2011). The Italian rail regulator has now less than four years operational work, which is short compared to all the other main European countries such as Great-Britain (The Office of Rail Regulation, - ORR, in 2003/2004), Germany (BNetzA, in 2006) or even Spain (CNMC, in 2010) or France (ARAF - Autorité de Régulation des Activités Ferroviaires, in December 2009/2010).

From 11 August 2004 to 14 January 2014, an independent office of the Ministry of Transportation, called Ufficio per la Regolazione dei Servizi Ferroviari (URSF), was responsible for Italian transport regulation (Stanta, 2013)3. It was established following the prescription of European legislation (Directive 14/2001) and it had various tasks as:

- Monitoring the competition and contestability degree of rail markets;

- Giving prescriptions to the national Infrastructure Manager (IM) on the rules and conditions in Network Statement;

- Resolving disputes between a RU and the IM or between two RUs on the allocation of the paths or other infrastructure services;

- Performing the compatibility check of new open-market or international passenger trains with an existing PSC.

The Italian transport regulator i.e. ART (Transport Regulation Authority) was created very recently, on 17 September 2013 by decree-law 6 December 2011 n. 201. It became operational from 15 January 2014. The Italian rail Regulator is a very new one and it has the wide mission to rule the whole Italian transport sector - all modes - by issuing technical regulations and promoting efficiency. This new body will completely take over the URSF and replace the

\footnotetext{
${ }^{2}$ According OECD (2001), the liberalization process brought Italy ahead of most European countries due to a completed liberalization of all railway transportation segments (p. 4 and p. 93).

${ }^{3}$ Legislative decree of 8 luglio 2003, n. 188 - Art. 37, which followed article 30 in the 2001/14/CE Directive.
} 
Ministry for many topics. This Authority rounded out the framework for the independent ex ante economic regulation of public services.

Following the European law (Directive 2012/34), the Regulator has to be fully independent from the government, from businesses and Infrastructure operators in order to avoid conflicts of interest. With a seven-year non-renewable mandate, the president and the members of the council may not be nominated members of the board of other independent authorities for at least five years, and are bound to a cooling-off period of two years. As a wholly independent body, the Authority is responsible to Parliament, to which it reports both within the framework of ad hoc thematic hearings and with a dedicated, yearly report of activities (Cambini and Perrotti, 2015).

Concerning its financing, except for an initial endowment from the State to enable the start-up ( $€ 4$ million for 2013-2014), the Authority raises its funding exclusively through fees from regulated businesses and based on yearly decisions which have to be in accordance with the Ministry of the Economy and Finance. The contribution could rate up to one per thousand of the business's turnover in the previous year (Cambini and Perrotti, 2015).

The Authority's main mission is the ex-ante economic regulation in the area of transport, covering both access to infrastructure and services:

- Ensuring the equitable and non-discriminatory access of businesses to transport modes;

- Setting the criteria on which to fix tariffs in all transport modes and industries, and both on the national and local levels;

- Contributing to defining public sector obligations;

- As to passengers' rights, the definition of minimum rights and entitlements.

Following the European law (Directive 2012/34), the set of powers conferred upon the Authority to carry out these responsibilities includes: a) issuing sanctions in several specific cases (nonimplementation of the Authority decision and if information requested by the Authority is refused); b) carrying out of investigations and on-site inspections; c) treating passengers' claims and complaints; d) signaling to the competent authorities the opportunity to terminate contracts, concessions and other forms of agreements; e) setting and demanding the application of criteria for the corporate separation and accounting separation of regulated businesses; f) stimulating and contributing to the definition of public sector obligations and the methods for financing them.

The Authority should probably enlarge its functions, according to the proposal for the Fourth Railway Package (EC, 2013), which strengthens the powers of the regulator in monitoring and arbitration, giving it an independent power of sanctioning.

The ART operates alongside the Italian Antitrust authority (AGCM) that is in charge of ex post regulation on individual cases. Although not fully devoted to transport, the Antitrust authority plays a key role in the rail industry. Many Antitrust decisions clarified relevant topics for competition and punished abuses of market power. Among them, can be mentioned: the size of the lots in competitive tendering, the conditions to treat some incumbent's assets as essential facilities, the temporary grouping of transport undertakings as a way to reduce competition. The Regional Governments often ask for the Authority's opinion when they are preparing tender specifications (Stanta, 2013). 
All the above points refer to the Italian rail regulation only 'in the book'. The following part will focus on the real practices of the Italian Rail Regulator in the field of HSR open access competition.

\subsection{The regulation of HSR open access competition in Italy: 'in practice'}

In order to understand how the Rail Regulator in Italy is concerned about the new HSR competition, we will investigate two aspects, a very official one and a much the more confidential and yet decisive one. On this section, we try to evaluate the behavior of the Rail Regulator with regard to the principles and methodologies of good governance established by the OECD (OECD 2008, 2014, Casullo and Zhivov, 2017).

\subsubsection{The main Italian Railway Regulatory official decisions}

From a legal and classical point of view of the regulation scheme, we will begin with examining and discussing the main Italian rail regulator decisions, according to the legal text (Cambini and Perrotti, 2015; ART website ${ }^{4,5}$ ).

The first ART railway regulation is Decision 70/2014, November 2014. It was preceded by a broad consultation of all stakeholders. This decision contains several measures in order to achieve an equitable and non-discriminatory access to railway infrastructures.

The major element of Decision 70/2014 is the very huge reduction of HSR network access charges. More precisely, the criteria applied by RFI to determine HSR access charges during 2015 led to a reduction of approximately $30 \%$ compared to the previous year, from $€ 12.8$ train $/ \mathrm{km}$ to $€ 8.2$ train/km. Previously, estimates of access charges for HST in Italy were around $€ 13.4$ per train/km average against $€ 3.4$ per train/ $/ \mathrm{km}$ average for conventional trains (Arrigo and Di Foggia, 2013; Stanta, 2013). International comparisons show, however, that HS tolls in Italy were already among the lowest in Western Europe (SNCF, 2015). This Decision of the ART confirms the line already taken by the Ministry a year ago, when a decree reduced by $15 \%$ the toll rates for HSR (II Fatto Quotidiano, 5 November 2014), while, over the same period, most other Western European countries are characterized by increases in railway tolls (SNCF, 2015). These successive reductions in railway tolls might demonstrate a steady and repeated desire to improve the competitiveness of the HS in Italy.

From an economic point of view, this reduction of HSR network access charges appears as a very important signal from the Italian Regulator.

In the short term, the reduction in tolls acts favorably on the financial balance of railroad companies, because the infrastructure tolls represent an important proportion of the total costs of railway operators. By some estimates, this measure should allow NTV to pay only $€ 65$ million of tolls in 2015, saving $€ 35$ million - and for Trenitalia $€ 140$ million, a decrease of $€ 80$ million (Charlier and Meillasson, 2015). By comparison, the amount paid on tolls equals all NTV's loss in 2014, which was $€ 37$ million (Table 5). Will it be sufficient to initiate a return to the financial balance of NTV? As Arrigo and Di Foggia (2013) say, 'The level and structure of the charges are therefore crucial to establish competition.' The high access charges limit the scope for profitable entry. It seems to be the case in France, where the access charges is around $€ 18.5$ per kilometre (SNCF, 2015). Conversely, lower track access charges help to

\footnotetext{
4 To have a complete information about the ART deliberations: http://www.autorita-trasporti.it/delibere/

${ }^{5}$ See also the URSF previous main decisions: http://www. mit.gov.it $/ \mathrm{mit} / \mathrm{site} . \mathrm{php}$ ? $\mathrm{p}=\mathrm{cm} \& 0=\mathrm{vd} \& \mathrm{id}=1245$
} 
promote and to make head-on competition commercially feasible, as it has been in Sweden (Preston, 2012; Vigren, 2017) and now in Italy too.

In the longer term, the effects of a change of access charges over the rail system concern many stakeholders (Álvarez-SanJaime and alii., 2016; Crozet, 2012; ECMT, 2005; Valletti and Estache, 1999), but are still very uncertain. For railway operators, a significant reduction in tolls may have a perverse effect about the reduction of the incentive to rationalize their services and their production costs.

For the Italian infrastructure manager (RFI- FS Group), the consequences of the ART toll measure may turn out to be unfavorable to its financial balance and thus to its capacity to finance the maintenance, the modernization and the development of the network. If the price effect is not offset by a volume effect, it will become harder to finance new rail HSR investments and, at the same time, to assume the IM debt.

If toll reduction translates into lower prices for travelers, it may have an impact on HSR demand, depending on its elasticity, and, in case of high load factor, a possible risk of saturation of the available capacity. The frequencies on HS lines in Italy were already very high. But, for the moment, tolls cut did not involve decrease of prices.

Besides, a toll reduction may favor certain traffics. Is there a risk to favor the high speed at the expense of other types of traffic, in particular long-distance traffic? This is less likely due to the declining trend of long-distance rail transport in Italy (Figure 2, above) and also because of competition from low cost airlines and long distance coaches.

At this time, it is difficult to say whether this Italian regulator decision to drop tolls sharply is more an opportunistic act than a sustainable choice? The question of how to calculate efficient rail tolls remains a delicate and debated issue. In Italy, rail tolls have long been kept quite low in order to make the entrance of new competitors easier (Ponti et al., 2007, Beria and Ponti, 2008). From rail economics regulation point of view (Finger and Messulam, 2015), we can observe that in an integrated railway system (i.e., the incumbent railway company still operates under a holding model, which is the case in Italy), the main role of the regulator is to support new entrants in case they feel discriminated against. From the perspective of good practice of the regulator with regard to the principles laid down by the OECD (OECD 2008, 2014; Casullo and Zhivov, 2017), the ART would be advised to expressly motivate the objectives sought by its decisions and evaluate their impact for the stakeholders.

\subsubsection{The underappreciated role of the everyday life of the Rail Regulator: trade-offs and discrete interventions}

Investigating the everyday life rail regulator interventions to overcome the practical barriers to fair competition is very meaningful. Small decisions are a main part of the job of a regulator with often no traces in the official books. For this part, we used information from ART website and annual reports, interviews of Italian Railroads regulation major players and Italian newspapers.

The rail industry, due to its very specific nature (Nash and Preston, 1992), with sub-additive costs, is characterized by many barriers to entry and exit. In this case, the competition scheme is not that of the classical model. The more appropriate theory of contestable markets (Baumol et al., 1983) suggests that, irrespective of the number of firms on the market, competitive positive effects could appear according to certain conditions. The key condition is that there are no barriers to entry and exit which, in turn, requires minimal sunk costs (Preston, 2012). In 
this case, all firms interested in this market fear the entry of a new comer and wouldn't be in a rent seeking strategy.

Preston (2012) highlights various cases of entry barriers, tangible and intangible, present in the rail industry, which are serious obstacles to fair competition. The main tangible entry barriers are the access to the infrastructure and to the rolling stock, due to poorly developed second hand market. The compulsory expenditures to have access to terminals, depots, maintenance facilities and to retail outlets are also detrimental sunk costs. Ensuring fair access to retail facilities, information and ticketing systems and computer systems reservation can also be more problematic (Pyddoke, 2011).

These tangible barriers are usually reinforced by less tangible ones. Among them, the 'innocent barriers' relate to what Button (1988) refers to as economies of experience, preferential access to capital and brand loyalty. These 'innocent barriers' might be reinforced strategically by reputational and size effects. Larger firms are able to withstand competitive battles longer than smaller ones and can develop strategy to blockade entry, by example, by saturating the key infrastructure paths.

Is the Italian HSR on-track competition fair? What are the main trade-offs and discrete interventions the rail regulator has to take?

Has there been discrimination against NTV to obtain slots in some stations or useful scheduling of its trains at the beginning? The fact is that NTV did not provide HSR services in several main railway stations unlike Trenitalia initially. For example, in Milan, NTV used to serve Milan Porta Garibaldi and Milan Rogoredo, but not Milan Centrale. Was it a deliberate NTV strategy to avoid entering the heart of the city, where speeds are reduced, or the result of lobbying Trenitalia on FSI? The truth is hard to find out. As for the initial lack of ticket machines in railway stations, NTV had also presented it as a positive element of its commercial offer, fully digital. Furthermore, the allegation of discrimination in the allocation of spaces has been rejected both by URSF and by the Antitrust Authority (AGCM).

Has there been administrative discrimination against NTV to make the start-up of Italo slower and harder? It took one year for NTV to obtain the railway license from the Ministry of Transportation. For the authorization from the Italian National Agency for the rail safety (ANSF) for the new AGV, obtained in March 2012, NTV had to wait 45 months (Stanta, 2013). But everywhere all rail undertaking had to face this major fact.

The Antitrust Authority issued several reports to clarify relevant matters about the access to the infrastructure. Then, on May 2013, it started a comprehensive investigation to check if RFI and Trenitalia abused of their powers. On March 12, 2014, the Italian Competition Commission (AGCM) closed the investigation and no evidence of abuse was found (Bergantino, 2015).

In 2016, NTV appealed in the Latium Court against the criteria defined by ART (Decision 96/2015) for determination of the access charge. NTV claims that RFI included in the HS tolls the financial charges related to the long term network investment, which run counter to European law (Directive 2012/34).

All these points underline the importance of the regulator independence from the infrastructure owner and from the incumbent. The latter also highlight the regulator's important work on a daily basis (Figure 1). 
Figure 1. Investigating the interventions of the Italian Rail Regulator to overcome the practical barriers to fair competition is very revealing

"The regulation of the HSR competition is more a daily practice that an elaborated and formal doctrine. This means finding the best balance to sustain competition and to obtain the best possible service for travelers. The regulation is mostly informal, by telephone, rather than by written procedures or legislations... The time of regulation is that of the markets and of competition, i.e. immediately. Adjusting the competition between Trenitalia and NTV is an ongoing balancing act (balance, trade off). The regulator does not want 'competition for the competition' but looking more services for citizens.

An example of intervention: the award of the Rome-Venice path. RFI did not provide a train path for NTV, claiming that there was a conflict between this request and the regional traffic. In response, the regulator had proclaimed: "You have to reach agreement before one week; otherwise, we will declare this line saturated." Trenitalia and RFI were then able to coordinate. Note that, in theory, NTV could even have benefit to a refusal to RFI in order to proclaim in the media the existence of unjustified barriers to competition! In Italy, the rail Regulator plays the role of a pragmatic facilitator to promote the interests of users without compromising the sustainability of the two main actors, in a context of preservation of local political balances."

Source: Interview of F. Croccolo, as former General Director of the URSF, the first Italian rail Regulator, on the 4 May 2015.

\section{The Italian HSR regulation outcomes: main success and uncertainties issues}

The analysis of the first years of this on-track competition from the rail regulator's point of view led to underline strong and undeniable successes, but also particularly delicate and uncertain matters.

\subsection{The main positives outcomes}

The new HSR competition and the updated Italian railway regulation design have objectively produced two main results which profoundly alter mobility patterns in Italy.

\subsubsection{A strong supply shock for high consumer benefits}

As suggested by theory, HSR competition in Italy has produced a triple competitive effect: more capacity, frequency and connections, lower prices and better services for high consumer benefits.

Firstly, the entrance of NTV obviously contributes to increase the overall supply of high speed trains in Italy. Supply for HSR trains constantly increased since 2009, when the incumbent started to run high speed services on its upgraded lines, even before on track competition. By 2012, NTV had added approximately $45 \%$ to the existing Trenitalia HSR supply on the major axis Turin-Milan-Rome-Naples (Cascetta and Coppola, 2013). In 2012, Trenitalia provided 89 services on this axis each day, while NTV supplied 38 services. From a theoretical point of view, the new comer strategy makes sense because it has allowed NTV to benefit from positive economies of density and network economies (Preston, 2012).

While the competitor introduced new trains on the densest Italian HSR routes, the incumbent did not reduce its supply. Trenitalia's HSR services (the "Frecce") were increased (ART, 2015). As a consequence, the entrance of NTV in the HSR market produced an increased supply in many Italian corridors (Cascetta \& Coppola, 2014), also serving new stations in Rome and secondary stations in Milan.

Secondly, on-track competition has pressured HSR prices down. Trenitalia HSR prices started to decrease before NTV entrance. On the Milan-Rome route, one-way fares reduced an 
average of $31 \%$ between 2011 and 2012 according to Cascetta and Coppola (2014). The main reason is the new pricing structure and availability of promotional offers, with a similar effect to the introduction of low-cost flights in the air market. Prices continued to decline with the arrival of NTV, but the incumbent did not trigger a price war. Considering the lowest fare on the main routes (Rome-Milan, Rome-Venice, Rome-Turin), in 2013 the incumbent's tariffs were $30-35 \%$ higher than those of NTV (Bergantino et al., 2015). On minor route, such as MilanAncona route, Trenitalia reduced the cheapest second class fares applied for advancedbooking by about 15\%, but not for the business class (Beria et al., 2016). On this route (opened in 2013) NTV started its activities being the cheapest operator but "ended up being more expensive for comparable services". As for Mazzola (2014), HSR prices are much lowest on main route in Italy than in France, 50-55\% for Milan-Rome compared with Lyon-Paris in 2013.

Thirdly, on-track competition had positive effects on supply of on-board services. Italo introduced itself in the Italian HSR market with a high-quality services strategy. This competitive behaviour pushes Trenitalia to respond by re-launching its own HS service. Bergantino (2015) observes that Trenitalia has refurbished its own trains to offer four classes of services and ordered a new fleet designed to be the fastest in the world. The two HS Italian operators seem to compete more on the quality of services than on travel time or prices. The competitive advantage aims at customer satisfaction by the various levels of services and the very high frequency.

\subsubsection{Mobility behaviours deeply modified in favour of HSR, but not really in favour of rail}

This open access HSR competition has contributed to change the share of the HSR in passenger rail traffic substantially, and so as the share of rail in all journeys, particularly in high traffic corridors.

In Italy, HSR demand has been truly booming, since 2009, and even more since 2012. The year 2009 corresponds to the completion of the network in its current configuration. The number of passenger-kilometres increased from 8.9 million in 2008 to 10.8 million in 2009, and continued to increase with 12.8 million in 2012 (Figure 2 from EC data) ${ }^{6}$. This HSR traffic growth is about 4 million passenger-kilometres and more in 4 years or an increase of about $44 \%$. Based on F. Croccolo data's (Table 4), the progression is even stronger and more constant with about 16.4 millions of passenger-kilometres for 2016, which represents an increase of $90 \%$ since the end of 2011 , just before the arrival of NTV.

This fact is all the more remarkable during this period hit by the consequences of the economic crisis, which tends to lead to stagnation or even reduction in mobility. In Italy, the decrease for all passenger transport was almost 18\%, expressed in passenger-kilometres, between 2005 and 2012, and 30\% for goods, expressed in tonne-kilometres, between 2005 and 2013 (ART 2015, p. 10).

\footnotetext{
${ }^{6}$ We observe a very strange fact in EC HSR data (EC, 2017; Table 2.3.8). Since 2012, the beginning of the Italian HSR competition, the number of passenger-km does not move any more. This fact is probably no reality as we see with $\mathrm{F}$. Croccolo data below. Curiously, ART annual reports do not give complete data on HSR traffic, either for Italy or by company.
} 
Figure 2. Italian rail transport markets

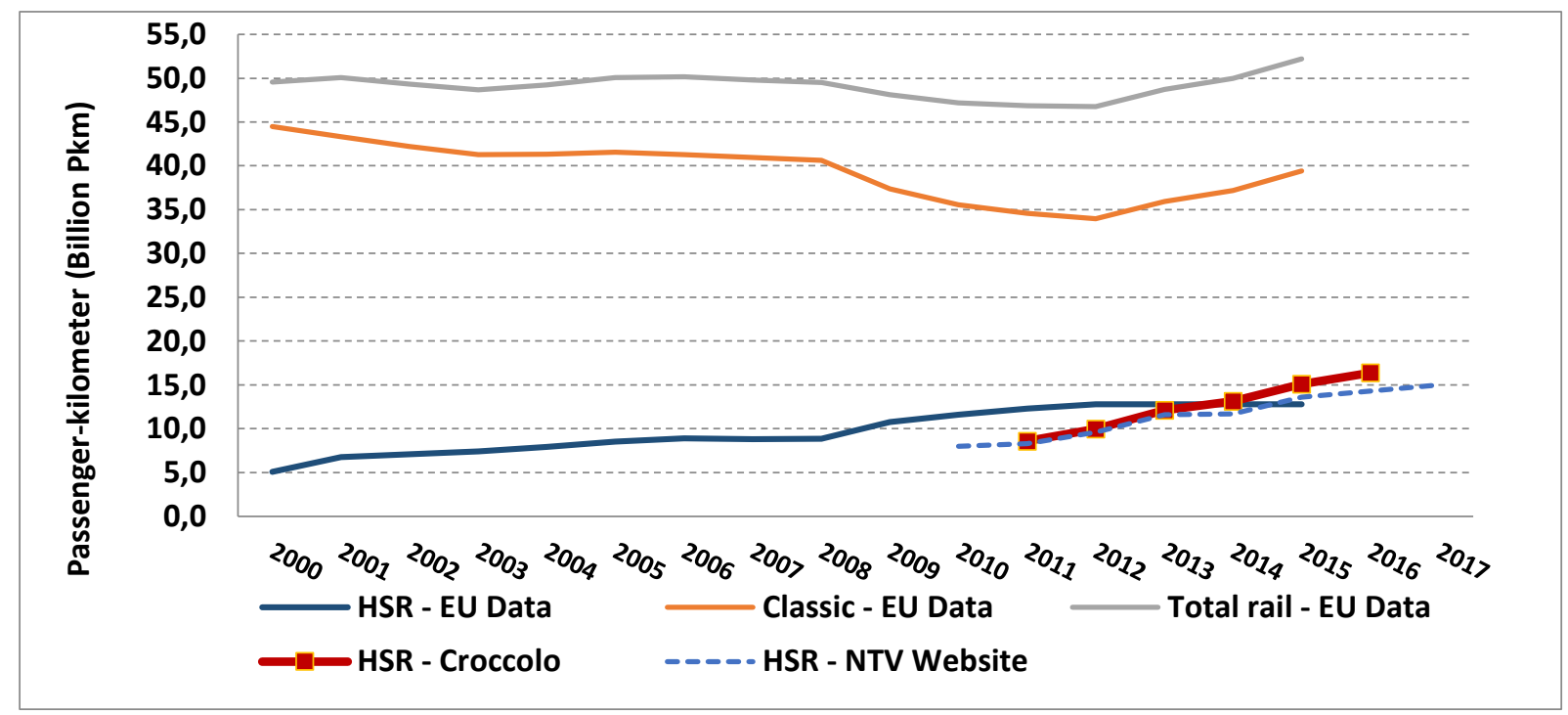

Source: Adapted from EC (2017). EU Transport in figures 2016. IRG Rail 2017; Croccolo.

But at the same time, demand for Trenitalia's services on conventional lines ${ }^{7}$ dropped where it introduced HSR trains, which offsets these gains, e.g. on the Milan-Rome line (Bergantino et al., 2015). However, the rise of high-speed in Italy has not yet succeeded in increasing the total rail passenger traffic, unlike all other European countries (Figure 2). The number of passenger-kilometres in 2014 was 50.0 million, very close to its previous peak in 2006 (50.2 million of passenger-kilometres), but only slightly better than the lowest point of 2012 with 46.76 million of pkm (EC, 2016).

As a result of the rise of the HSR in this stagnation context of total rail passenger traffic, the share of high speed has particularly increased in the total Italian railway transport. In 10 years' time the high speed rail share nearly doubled, going from $14.4 \%$ to the maximum of $28.7 \%$ in 2012, to the European average, but without reaching the high market shares of HSR achieved in Spain or in France (Figure 3).

Figure 3. Share of high speed traffic in Europe

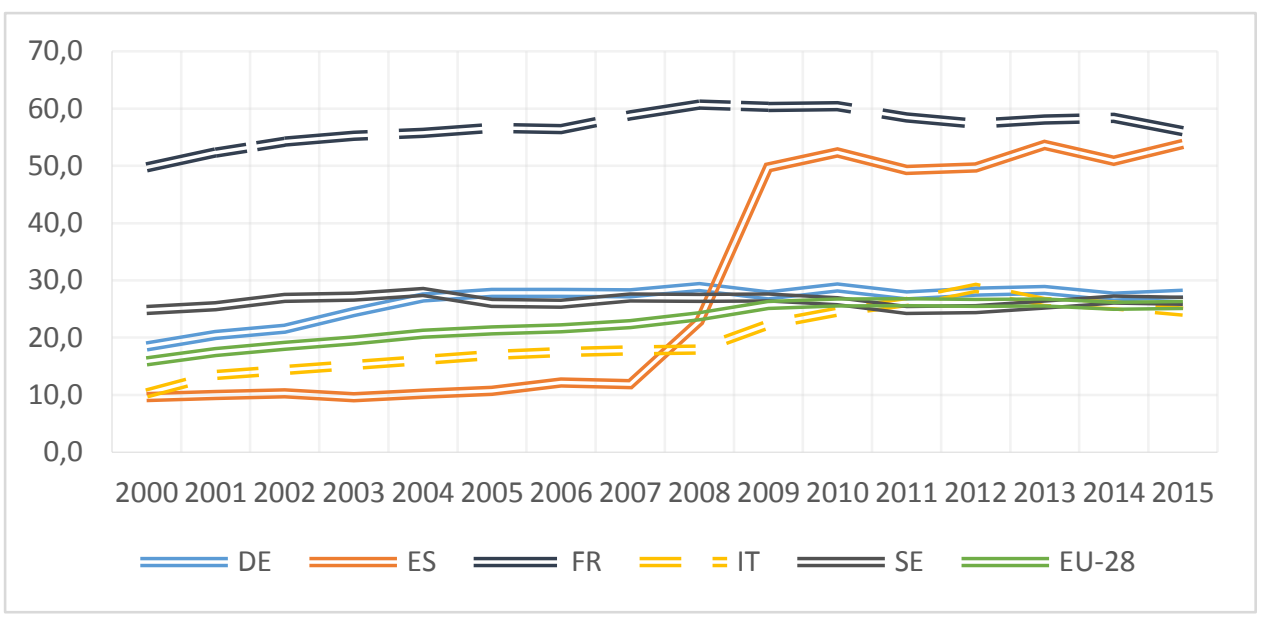

Source: Adapted from EC (2017), Tab. 2.3.8. EU Transport in figures 2017.

7 The classic rail traffic curve was derived from the EC data by calculating the difference between total passenger rail traffic and HSR. As the latter is reduced, classic traffic is logically overestimated. 
Nevertheless, with a low overall progression of the rail, in a global context of reduced mobility, the modal share of rail improves slightly lately: 5.5\% in 2009 and 2010 , it increased to $5.7 \%$ in 2011 and $6.4 \%$ in 2012 - but down to $6.2 \%$ in 2015 (EC., 2017).

As an impressive result of the open access HSR competition, we observe a significant change of the modal split in favor of rail to the detriment of air services (Bergantino et al., 2015; Cascetta and Coppola, 2013; Mancuso, 2014). On the Rome-Milan route, which is in Italy the largest in terms of number of passengers, the modal shares of air, car and train travel had been deeply influenced by the introduction of HSR. From 2008 to 2014, the rail modal share increased significantly, from $36 \%$ to $65 \%$. Passenger on airplanes halved (from $50 \%$ to $24 \%$ ) and travel by car or bus was reduced from $14 \%$ to $11 \%$ (ART, 2015). These trends began before the arrival of the competition, and the arrival of NTV in 2012 has extended them. In such a route, air and rail travelling times are now very similar, and the transport modes can be considered as substitutes.

HSR has also induced broader changes in mobility beyond modal choice. In the long term, HSR demand is linked to travellers' lifestyle choices (Croccolo and Violi, 2013). HSR has opened the possibility of commuting further than in the past. Higher frequency and connections between the major Italian cities centers, coupled with lower prices as a consequence of competition, lead for commuters to a higher attractiveness. Indeed, HSR creates new possibilities for work-related travel including return journeys, and 'macro residential areas' as a result of increased regional integration. This is the reason why the HSR network and trains in Italy have been dubbed "Italy's metro".

In view of the principles of good governance of regulation prescribed by the OECD (OECD, 2008, 2014, Casuallo and Zhivov, 2017), it is a startling fact that the Italian Rail Regulator does not seek to give more transparency and does not produce official data on this exemplary railway competition.

\subsection{The main risks and uncertainties}

For the moment, all the impacts of this new rail structure passenger market and of the new Italian rail regulatory policies and practices have not yet fully occurred. Two major issues remain particularly uncertain for now: the effects of HSR competition for all Italian railway actors and the economic and financial equilibrium of the new comer, NTV.

\subsubsection{A "win-win game": positive effects for the all Italian railway system?}

Could we argue that the introduction of competition in HSR has delivered positive effects to the entire railway system (Croccolo and Violi, 2013)? Two observations support this hypothesis, the first concerning Trenitalia and the second regarding RFI.

Despite the progression of the new comer on HSR market, Trenitalia is still dominating the Italian HSR market and resists competitive pressures, with a HSR market share around 75$80 \%$ at the end of 2016 , even though its market shares are continually declining (Table 4 , below). Between the end of 2011 and the end of 2016, the number of passengers on HST for Trenitalia increased by $45 \%$ and by $35 \%$ expressed in passenger-kilometres.

HSR competition came along with an increase in the total market and did not reduce the demand for the incumbent. We can suggest, following Bergantino (2015), that the incumbent is defending its national market and tackling the new business. According to the person in charge of the international affairs of Trenitalia (Mazzola, 2015), the competition was very useful for Trenitalia to reform itself and for trade unions to accept an agreement that brought more 
versatility, increased working time and therefore productivity gains. On-track competition may appear as an additional lever for a long-term managerial project.

In this demanding context, the Italian national railway operator shows positive and increasing operating profits. This improvement makes Trenitalia one of the most profitable railways in Europe (A. Mazzola, 2014). This operating profit growth is due to the continuously drastic reduced operating costs and not to the trend of operating revenues which, as other major railways, are no longer increasing (Table 2). The analysis of Trenitalia's income is particularly difficult because of the detrimental impact of the economic crisis on traffic, both freight and travellers and because Trenitalia's financial statements do not disaggregate its revenues by market segment.

Table 2. Trenitalia: Economic and financial performances

\begin{tabular}{|c|c|c|c|c|c|c|c|c|}
\hline Millions Euro & 2007 & 2009 & 2011 & 2013 & 2015 & 2016 & $\begin{array}{l}\text { Variation } \\
2016 / 2007\end{array}$ & $\begin{array}{c}\text { Change since } \\
2007 \text { in \% }\end{array}$ \\
\hline $\begin{array}{l}\text { Operating } \\
\text { revenues }\end{array}$ & 5521 & 5638 & 5708 & 5498 & 5114 & 5079 & -442 & $-8,0$ \\
\hline Operating costs & 5281 & 4656 & 4317 & 4113 & 3634 & 3684 & -1597 & $-30,2$ \\
\hline $\begin{array}{l}\text { Operating profit } \\
\text { (EBITDA) }\end{array}$ & 240 & 982 & 1391 & 1385 & 1480 & 1395 & 1155 & 481,3 \\
\hline
\end{tabular}

Source: Trenitalia, Financial Statements.

Secondly, we observe that the on-track competition produced some positive effects on the infrastructure manager, RFI. Bergantino et al. (2015) report a greater utilization of the network. As a result, we suggest that with the introduction of HSR, RFI benefited from an increase of HSR access charges (toll revenues). RFI's financial statements seem to confirm this assumption, though HSR tolls and conventional lines tolls are not separately identified (Table 3).

Table 3. RFI: Revenues from sales and services (thousands of Euro)

\begin{tabular}{lrrrrrrr}
\hline Millions Euro & 2009 & 2011 & 2012 & 2013 & 2014 & $\begin{array}{c}\text { Variation } \\
2014 / 2009\end{array}$ & $\begin{array}{c}\text { Change since } \\
2009 \text { in \% }\end{array}$ \\
\hline State grants & 849,3 & 975,4 & 110,4 & 150,4 & 975,6 & 126,3 & 14,9 \\
Tolls & 903,1 & 969,5 & 128,6 & 103,2 & 1051,2 & 148,1 & 16,4 \\
Electric traction & 77,0 & 79,0 & 75,0 & 76,0 & 93,4 & 16,4 & 21,3 \\
Ferry services & 31,8 & 22,3 & 20,5 & 18,1 & 18,0 & $-13,8$ & $-43,4$ \\
Total & 161,2 & 2046,2 & 2234,5 & 247,7 & 2138,1 & 276,9 & 14,9 \\
\hline
\end{tabular}

Source: Adapted from RFI, Financial Statement, 2010-2014.

We observe a 148 million Euros increase in total toll revenue over the period 2009-2014. In 2014, toll revenue fell slightly, probably because of Ministerial Decree n.330 (10 September 2013), which reduced by $15 \%$ the tolls due to RFI on the HSR tracks. We do not know yet the impact of the last ART decision 70/2014 which further significantly reduced HSR tolls. The evidence above suggests that higher traffic volumes on the HSR network could be able to compensate for the lower price. 
More generally, as suggested by Croccolo and Violi (2013), investment in high-speed rail is also having knock-on effects for the conventional network. It enlarges sections which are useful for commuting or goods traffic. The faster speed also frees up capacity on the network. Moreover, network deployment also enabled a substantial investment in railway stations and urban hubs, a field where Italy is a world leader, not least because of the difficulties of crossing historically and culturally important cities.

If the investments in new or upgraded lines weigh heavily on Italian taxpayers (Beria and Ponti, 2008), they should probably be evaluated for the whole community, in light of the benefits which may be important. But there is still debate and only a few studies. Bergantino et al. (2015) suggested significant reduced fares when flights are in direct competition with HSR services. Beria and Grimaldi (2016), through a cost-benefit analysis, give a marginally positive result in the most-likely case, mainly due to competition more than to investment in HS lines.

\subsubsection{The NTV business story: A commercial success, but a financial failure?}

After four operational years, what are the commercial and financial results of the new comer?

The first meaningful result is that NTV's commercial challenge was won. NTV succeeded to enter quickly and deeply in this very specific HSR market, with the significant $20 \%$ market share in only two years (Table 4). Moreover, the announced targets of market share had been reached properly. NTV expected 8-9 million passengers per year by 2015 ; the goal was achieved in 2015, with 9.1 million.

Following our own data (Croccolo F., 2017), the recent years confirm the ongoing positive commercial trend. In 2016 NTV carried 11,1 millions of passengers and its performance was even better expressed in passenger-kilometres, with 4,8 million (respectively $24.6 \%$ and $29.2 \%$ market share). Load rates (passenger-kilometres / seat-kilometres) posted by the company are recently high, showing a strong growth, with $77.4 \%$ in 2017 against $51.7 \%$ in 2014 (NTV, 2017). These successes are largely communicated by the company, which, until 2014 , did not broadcast hardly any commercial results on its website or in its official reports.

Table 4. Italian HSR: NVT and Trenitalia's market shares

\begin{tabular}{|l|c|c|c|c|c|c|c|c|c|c|c|c|}
\hline \multirow{2}{*}{} & \multicolumn{2}{|c|}{2011} & \multicolumn{2}{c|}{2012} & \multicolumn{2}{c|}{2013} & \multicolumn{2}{c|}{2014} & \multicolumn{2}{|c|}{2015} & \multicolumn{2}{|c|}{2016} \\
\cline { 2 - 12 } & $(\mathrm{a})$ & (b) & (a) & (b) & (a) & (b) & (a) & (b) & (a) & (b) & (a) & (b) \\
\hline Trenitalia & 23,4 & 8,6 & 25,1 & 9,1 & 26,2 & 9,5 & 29,1 & 10.4 & 31,2 & 11,09 & 34,0 & 11,6 \\
& $100 \%$ & $100 \%$ & $92,4 \%$ & $91,1 \%$ & $80,9 \%$ & $78,3 \%$ & $81,6 \%$ & $79 \%$ & $77,4 \%$ & $73,6 \%$ & $75,4 \%$ & $70,8 \%$ \\
\hline NTV & 0,0 & 0,0 & $\begin{array}{c}2,05 \\
7,6 \%\end{array}$ & $\begin{array}{c}0,89 \\
8,9 \%\end{array}$ & $\begin{array}{c}6,2 \\
19,1 \%\end{array}$ & $\begin{array}{c}2,63 \\
21,7 \%\end{array}$ & $\begin{array}{c}6,55 \\
18,4 \%\end{array}$ & $\begin{array}{c}2.76 \\
21,0 \%\end{array}$ & $\begin{array}{c}9,15 \\
22,7 \%\end{array}$ & $\begin{array}{c}3,98 \\
26,4 \%\end{array}$ & $\begin{array}{c}11,077 \\
24,6 \%\end{array}$ & $\begin{array}{c}4,78 \\
29,2 \%\end{array}$ \\
\hline $\begin{array}{l}\text { Italian } \\
\text { HS } \\
\text { market }\end{array}$ & 23,40 & 8,60 & 27,15 & 9,99 & 32,40 & 12,13 & 35,65 & 13,16 & 40,35 & 15,07 & 45,08 & 16,38 \\
\hline
\end{tabular}

Source: NTV; Trenitalia; F. Croccolo. (a): Passengers in million; (b): Passengers * $\mathrm{Km}$ in billion.

For the NTV shareholders, the first years were financially particularly disappointing. The results were much lower than expected (Patuelli, 2015). But, since 2014, the financial situation has improved significantly (Table 5). More precisely, 2012 was the worst year: debt exploded up to the equivalent of 4 years of revenue, due to the very sharp deterioration in operating results (almost 140 million Euros loss for 100 million revenues). Since then, revenues have continued to grow while costs have successfully been well controlled. The operating result has become more and more positive (since 2015), just like the net profit. Since its peak in 2012, its debt has been drastically reduced by almost 30\%, at the end of 2017. In December 2017, NTV 
shareholders announced their intention to float on the stock market. In February 2018, they accepted an offer to be sold by the US GIP fund (Global Infrastructure Partners) for 1.98 billion Euros. The financial bet of the NTV shareholders NTV seems won today.

Table 5. NTV financial results

\begin{tabular}{lccccccccccc}
\hline \multicolumn{1}{c}{ Millions $€$} & 2008 & 2009 & 2010 & 2011 & 2012 & 2013 & 2014 & 2015 & 2016 & 2017 & Total \\
\hline $\begin{array}{l}\text { Operating } \\
\text { revenue }\end{array}$ & 0,2 & 1,5 & 4,5 & 24,7 & 102,9 & 249,6 & 267,8 & 307,8 & 364,4 & 454,9 & 1778,4 \\
Operating cost & 4,1 & 13,5 & 25,1 & 51,8 & 214,1 & 284,0 & 281,5 & 254,0 & 269,5 & 313,0 & 1710,5 \\
EBITDA & $-3,9$ & $-12,0$ & $-20,6$ & $-27,1$ & $-111,2$ & $-34,4$ & $-13,7$ & 53,8 & 95,0 & 142,0 & 67,9 \\
Operating Profit & $-3,9$ & $-12,2$ & $-21,7$ & $-41,5$ & $-137,2$ & $-77,5$ & $-50,8$ & 21,2 & 62,4 & 112,5 & $-148,9$ \\
(EBIT) & $-5,6$ & $-13,2$ & $-20,7$ & $-39,3$ & $-77,1$ & $-77,6$ & $-62,0$ & 12,6 & 32,7 & 33,8 & $-216,5$ \\
Net Profit & 89,0 & 103,0 & 104,0 & 196,0 & 592,4 & 609,7 & 631,9 & 540,8 & 538,2 & 443,0 & \\
Net Debt & & & & & & & & & \\
\hline
\end{tabular}

Source: 2008-2011: From Patuelli (2015); 2012-2017: Adapted from NTV financial statements.

Finally, we suggest this prediction: "Italy cannot afford NTV's bankruptcy. NTV will be profitable." (Croccolo F.; Interview 2015). Was it only a wish or a rationally founded idea?

The ART should play a more active role in overcoming these uncertainties by becoming more involved in socio-economic assessment missions of public transport policies. To this end, it should make good use of the OECD methodological proposals (OECD, 2008, 2014), in particular those called "Regulatory Impact Analysis" (RIA). For this purpose, it would be necessary for the Legislator to entrust the Regulator with this mission.

\section{Conclusions}

In conclusion, we can draw some results and a few lessons. In our point of view, this paper brings seven meaningful results.

1. The open access HSR Italian competition took place in a very contradictory context: a very ambitious and innovating new comer who arrives quickly and deeply in the HSR market coupled with strong reactions from the incumbent, while the railway passenger demand is declining and the macroeconomic environment unfavorable.

2. Italian State played a very active and positive role to promote this open access HSR competition by the large public financing of the new HSR dedicated network.

3. Before many other Western European countries, the Italian rail institutional framework has responded to the European model of rail liberalization, but more in the law than really in practice. In rail domestic passengers market, there was no real competition until NTV's entrance. In comparison with the other major European countries, the Italian railway regulator (ART) appears to be late to comply with European law.

4. Italian open access competition seems to be fair. In spite of the complaints regularly lodged by the latter, rail regulator's decisions show that there is no blatant evidence of major anticompetitive behaviour against the new operator. The railway regulator plays an important role in the implementation of European law in favour of fair and undistorted competition.

5. The Italian railway regulator led a long term voluntarist policy of low track access charges, which distinguishes Italy from most of the other European countries and seems a key factor of the success of the on track HSR competition. We can suggest that this policy of tolls aims at 
two objectives: to boost the expansion of the high-speed rail market in Italy, but perhaps also, to facilitate the entrance of the new competitor and the reach of its economic equilibrium.

6. The previous Italian rail economic regulation seems to be more empirical decisions than a duly achieved economic doctrine and policy. In practice, it is often everyday life decisions to try to balance and to trade-off the competition in favour of the ultimate benefit of consumers and taxpayers.

7. On track competition could produce a 'win win' situation between all railway actors. Obviously, the most advantages are for passengers: more supply, more frequency, more differentiated services at lower prices and the possibility to choose. The evidence is currently not sufficiently established or conclusive as regards the incumbent, the new entrant and the infrastructure manager feasible in solving the major capacity constraints, even on the busiest routes.

Which lessons can be drawn from this case study for policy makers?

First, the success of the HSR on track competition in Italy is significant. It means that open access competition could be both technically feasible and socially desirable on a large scale, mainly due to the positive effects for passengers. It has a meaningful economic impact in terms of increasing the efficiency of both players, who have undertaken to produce more and better with limited resources (Croccolo and Violi, 2013). However, this new competition still does not answer the question whether all companies involved in HSR open access competition, especially the new comer NTV, reach their economic equilibrium.

Secondly, the successful aspects of this Italian HSR on track competition bring strong support to the European liberalization railway policy, i.e. the forthcoming Fourth Rail Package. The Italian case advocates for more competition in the domestic passenger market and especially in the unsubsidized services. Since now, competition was only compulsory for international passenger lines.

Thirdly, the very specific factors of the Italian situation lead to a cautious forecasting open access impacts and regulation patterns in others European countries (Croccolo, 2013). It would be not really scientific to try to generalize Italian rail HSR competition and regulation experiences. However, our study period is particularly short and also impacted by the consequences of a serious and European wide economic crisis. Further researches will be needed to allow a more mature opinion on all these complex features.

Fourthly, from the perspective of the regulator's best practices in the light of the principles laid down by the OECD, the Italian Transport Regulator had better comply more with the principles of good governance. It is supposed to inform the public debate on the effects of this competition in high speed by producing regular and reliable data and by proposing assessments of its effects on all stakeholders and on the well-being of the whole society.

\section{References}

ÁLVAREZ-SANJAIME Ó., CANTOS-SANCHEZ P., MONER-COLONQUES R., SEMPEREMONERRIS J., 2016. Rail access charges and internal competition in high speed trains. Transport Policy 49, 184-195.

ANSELMI, L., 2014. Percorsi aziendali per le pubbliche amministrazioni: Edizione rivista ed ampliata. G Giappichelli Editore. 
ART (Autorità di Regolazione dei Trasporti), 2014, 2015, 2016, 2017. Rapporto Annuale al Parlamento.

ARRIGO, U., DI FOGGIA, G., 2013. Competition and pricing of essential inputs: The case of access charges for the use of the Italian rail infrastructure. UTMS Journal of Economics, 4 (3): 295-307.

BALDWIN, R., CAVE, M., LODGE, M., 2012. Understanding regulation: Theory, Strategy and Practice. Oxford University Press, 2nd edition, Oxford.

BARON L. and CIRY B., 2012. NTV : nouvel opérateur ferroviaire à grande vitesse. Revue Générale des Chemins de Fer, 217. Juin. 32-44.

BAUMOL, W.J., PANZA, J.C., WILLIG, R.D., 1983. Contestable markets: An uprising in the theory of industry structure: Reply. American Economic Review, Vol. 73/3, 491-96 (June).

BERGANTINO, A.S., CAPOZZA, C. CAPURSO, M., 2015. The impact of open access on intra - and inter - modal rail competition. A national level analysis in Italy, Transport Policy, 39, 7786.

BERGANTINO, A.S., 2015. "Incumbents and new entrants" in: FINGER, M., MESSULAM, P. (eds), Rail Economics, Policy and Regulation in Europe Cheltenham, UK and Norththampton, MA: Edward Elgar.

BERGANTINO, A.S., 2016. "Open Access Passenger rail Competition: the case of Italy". Round Table. Masarykova Univerzita, Brno. $11^{\text {th }}$ November.Slides.

BERIA, P. and PONTI, M., 2008. "The role of regulation in financing transport infrastructures in Italy," MPRA Paper 14108, University Library of Munich, Germany.

BERIA, P. and GRIMALDI, R., 2016. An ex-post cost benefit analysis of Italian High Speed train, five years after. Working papers SIET 2016.

BERIA, P., REDONDI, R., MALIGHETTI, P., 2016. The effect of open access competition on average rail prices. The case of Milan-Ancona, Journal of Rail Transport Planning \& Management, 6, 271-283.

BUTTON, K.J., 1988. "Contestability in the UK bus industry, experience goods and economies of experience", in Bus Deregulation and Privatization: an International Perspective (Dodgson and Topham Eds), Avebury and Brookfield, 1988.

CAMBINI C. and PERROTTI L., 2015. The New Transport Regulation Authority in Italy: Structure, Competencies, and First Regulatory Decisions, March, 54.

CASCETTA and COPPOLA, 2013. Competition on the fast track: a short term analysis of the first competitive market for HSR services. EWGT2013 - 16th Meeting of the Euro Working Group on Transportation.

CASULLO L., 2016. The Efficiency Impact of Open Access Competition in Rail Markets. The Case of Domestic Passenger Services in Europe. Discussion Paper 2016, 07 International Transport Forum, Paris, OECD.

CASULLO L., and ZHIVOV N., 2017. Assessing Regulatory Changes in the Transport Sector. An introduction, Discussion Paper No. 2017-05, International Transport Forum, Paris, OECD.

CESARINI A., 2013. Is there a 'Latin way' of regulating railways? The view of the Italian incumbent operator. 7th Florence Rail Forum. FSR, Florence, November 29, 2013. 
CHARLIER, L., MEILLASSON, S., 2015. "NTV : développer l'offre et la marque". La Lettre ferroviaire, 127. 17 March 2015.

CROCCOLO F. and VIOLI A., 2013. New Entry in the Italian High-Speed Rail Market. OECDITF. Discussion Paper 2013-29. New Delhi, December 18-19, 2013.

CROCCOLO F., 2015. Interview as former General Director of the URSF, the first Italian rail Regulator, on the 4 May 2015.

CROZET, Y., 2012. Infrastructure management: how to deal with the 'quiet life' of a natural monopoly? In CERRE Policy paper. Brussels.

EC., 1996. White Paper of 30 July 1996: "A strategy for revitalising the Community's railways". COM/96 Final. Brussels.

EC., 2001. White Paper submitted by the Commission on 12 September 2001: "European transport policy for 2010: time to decide". COM 2001/370.

EC., 2011. European Commission - Directorate-General for Mobility and Transport. White paper. Roadmap to a Single European Transport Area - Towards a competitive and resourceefficient transport System, Brussels.

EC., 2017. EU Transport in figures 2017. Statistical pocketbook. Luxembourg.

ECMT - European Conference of Ministers of Transport, 2005. Railway reform and charges for the use of infrastructure. Paris: OECD.

FINGER, M. and KÜNNEKE, R. W. (eds) 2011. International Handbook of Network Industries: The liberalization of Infrastructure, Edward Elgar Publishing. Cheltenham, UK and Northampton, MA.

FINGER, M. and MESSULAM P., 2015. "Rail economics and regulation" in: FINGER, M., MESSULAM, P. (eds), Rail Economics, Policy and Regulation in Europe, Edward Elgar, Cheltenham, UK and Norththampton, MA.

IRG-Rail, 2017. Fifth Annual Market Monitoring Report, March 2017.

KNIEPS, G., 2015. "Competition and third-party access in railroads" in: FINGER, M., MESSULAM, P. (eds), Rail Economics, Policy and Regulation in Europe, Edward Elgar, Cheltenham, UK and Norththampton, MA.

FSI, 2015. 2014 Financial Annual Report. Rome.

MANCUSO, P. 2014. An analysis of the competition that impinges on the Milan-Rome intercity passenger transport link. Transport Policy, 32, 42-52.

MAZZOLA, A., 2014. The Italian High Speed Rail system in Transforum meeting. Roma, June $12,2014$.

MAZZOLA, A., 2015. Interview as responsible for international affairs of Trenitalia, on the 4 May 2015.

NASH C. and PRESTON J., 1992. Barriers to entry in the Rail Industry. WP 354. ITS. University of Leeds.

$\mathrm{NASH}, \mathrm{C} ., 2008$. Passenger railway reform in the last 20 years - European experience reconsidered. Research in Transportation Economics, 22, 61-70. 
NASH C., 2015. When to invest in high speed rail?, Journal of rail Transport Planning \& Management, 12-22.

NTV. Annuals Reports 2012, 2013, 2014, 2015, 2016, 2017.

OECD, 2001. Regulatory Reform in Italy. March. OECD. Paris.

OECD, 2008, Building an Institutional Framework for Regulatory Impact Analysis, OCDE Publishing, Paris.

OECD, 2013. "Recent developments in rail transportation services", Policy Roundtables on Competition and Regulation, 13 December, DAF/COMP/WP2/WD, 24.

OECD, 2014, The Governance of Regulators, OECD Best Practice Principles for Regulatory Policy, OCDE Publishing, Paris.

OECD, 2015. Economic Outlook 97 database. June. OCDE Publishing, Paris.

PATUELLI A., 2015. High-speed rail: is competition in the market sustainable? An Italian case. International Research Society for Public Management Conference 2015. University of Birmingham. 30 March - 1 April 2015.

PERENNES P., 2017. Open Access for Rail Passenger Services in Europe: lesson learnt from Forerunner Countries. Transportation Research Procedia 25C, 358-367.

PONTI, M., BERIA P., ERBA S., 2007. Una politica per i trasporti italiani, Laterza, Roma / Bari, Italy.

PONTI, M., BOITANI A., RAMELLA F., 2013. The European Transport policy: it's main issues. Case studies of Transport Policy, 1, 53-62.

PONTI, M., 2013. « Chi controlla i binari: la lezione del caso Italo ». II Fatto Quotidiano, 2 November 2013.

PONTI M., 2014a. «Italo, la lettera aperta di NTV e l'inerzia dello Stato anti-concorrenziale ». II Fatto Quotidiano, 4 September 2014.

PONTI M. 2014b. « Ferrovie: fare concorrenza agli Intercity. La proposta di Marco Ponti per il futuro dei treni NTV ». FerPress. 5 September 2014.

PRESTON, J., WHELAN G., WARDMAN M., 1999. An analysis of the potential for on-track competition in the British passenger rail industry. Journal of Transport Economics and Policy, 33(1), 77-94.

PRESTON, J., 2012. Competition and cooperation, organisations and markets: how to deal with barriers to entry and market powers in CERRE Policy paper "Beyond the quiet life of a natural monopoly: Regulatory challenges ahead for Europe's rail sector". Brussels.

SÁNCHEZ-BORRÁS, M., 2015. "High-Speed rail in Europe", in: FINGER, M., MESSULAM, P. (eds), Rail Economics, Policy and Regulation in Europe, Cheltenham, UK and Norththampton, MA: Edward Elgar.

SCIARRONE, G., 2014. From zero to Italo: so competition was born. NTV. Presentation to the European Passengers' Federation.

SENN L. and Cini T., 2011. Italy in Reforming Railways - Learning from Experience. CER, Eurail Press, Hamburg.

Sia Conseil, 2012. Italo : une Ferrari à très grande vitesse. 
SNCF, 2015. Benchmark européen des péages d'infrastructure. Lignes voyageurs longuedistance ou grande vitesse. Juin. Note de la Direction de la stratégie ferroviaire et de la régulation.

STANTA F., 2013. Twelve years of rail reform in Italy: achievements and problems. 13 th Thredbo conference - Oxford, September 15-19, 2013.

STEFANATO P., 2014. «Il futuro di Italo? Fare concorrenza agli Intercity». II Giornale.it, 5 September 2014.

TOMEŠ, Z., KVIZDA, M., JANDOVÁ, M., \& REDERER, V. (2016). Open access passenger rail competition in the Czech Republic. Transport Policy, 47, 203-211.

UIC, 2013. International Railway Statistics 2012. Paris.

UIC, 2014. High-speed lines in the world. Paris.

VALLETTI, T. M., ESTACHE A., 1999. The theory of access pricing: An overview for infrastructure regulators. Discussion Paper Series no. 2133. Centre for Economic Policy, London.

VICKERMAN R., 1997. High-speed rail in Europe: experience and issues for future development. The Annals of Regional Science, Vol. 31/1, 21-38.

VIGREN, 2017. Competition in Swedish Passenger Railway: Entry in an open access market and its effect on prices. Economics of Transportation, vol. 11-12, 49-59. 